\title{
Worker Ownership and Section 8(a)(2) of the National Labor Relations Act
}

\author{
American workers have long experimented with employee ownership of
} the industrial workplace. ${ }^{1}$ Until recently, such experiments were sporadic and usually unsuccessful, overshadowed in the labor movement by the dominance of national trade unions and their focus on collective bargaining. ${ }^{2}$ In the last decade, however, the idea of the worker-owned firm has achieved a new visibility. Such firms are now estimated to number between ninety and two hundred, ${ }^{3}$ and the number continues to grow ${ }^{4}$ as groups of employees, in an effort to preserve their jobs, attempt to purchase plants about to be closed by corporate owners. ${ }^{5}$ Although worker-owned firms in the United States today vary widely in size and operation, ${ }^{6}$ most, by their nature, exhibit some degree of worker participa-

1. Thomson, Employee Owned Companies: A New Look at an Old Phenomenon, MERGERS \& ACQUISITIONS, Spring 1976, at 6.

2. Many early attempts at worker ownership involved producer cooperatives established by members of a particular trade seeking to preserve their status in a world of rapid industrialization. $1 \mathbf{P}$. FONER, HISTORY OF THE LABOR MOVEMENT IN THE UNITED STATES 179-81 (1947). Most of these cooperative enterprises failed, and with the growth of national trade unions, the labor movement instead focused primarily on the benefits workers could obtain from employers through collective bargaining and unionization. See Gurdon, An American Approach to Self-Management, in WORKER PARTICIPATION 295, 295 (H. Jain ed. 1980).

3. Compare SElect COMM. ON SMall Business, 96TH CONG., 1ST SeSS., THE ROLE OF THE FEDERAL GOVERNMENT AND EMPLOYEE OWNERSHIP OF BUSINESS iii (Comm. Print 1979) lhereinafter cited as SENATE COMM. ON SMALL BUSINESS] (employees hold majority interests in at least 90 firms in United States) with Long, Effects of Employee Ownership on Organizational Identification, Employee Job Attitudes, and Organizational Performance: $A$ Tentative Framework and Empirical Findings, 31 HUM. REL. 29, 31 (1978) (approximately 200 worker-owned firms in United States).

4. See Small Business Employee Ownership Act: Hearings on S. 388 Before the Senate Comm. on Small Business, 96th Cong., Ist Sess. 120-21 (1979) (statement of William F. Whyte, Professor of Industrial Relations, Cornell University) (employee-owned firms spreading rapidly) [hereinafter cited as Hearings on S. 388]. Approximately $80 \%$ of existing worker-owned firms were formed after 1971, and approximately $57 \%$ of those firms were formed after 1975. SENATE COMM. ON SMALL BUSINESS, supra note 3 , at 1 .

Two factors seem to explain the recent surge in worker ownership. First, attempts at worker ownership tend to proliferate during periods of industrial recession and high unemployment (such as the 1970 's) as workers seck to protect their jobs. Gurdon, supra note 2 , at 295 . Second, various forms of government assistance, ranging from tax incentives that encourage the use of Employee Stock Ownership Plans to federally subsidized loans from agencies such as the Economic Development Administration of the Commerce Department, now somewhat lessen the financial obstacles faced by workers seeking to buy their companies. See Ross, What Happens When Employees Buy the Company, ForTUNE, June 2, 1980, at 108-09; Stern \& Hammer, Buying Your Job: Factors Affecting the Success or Failure of Employee Acquisition Attempts, 31 HUM. REL. 1101, 1109 (1978).

5. Approximately $70 \%$ of the worker-owned firms formed in the last decade were purchased by workers seeking to save their jobs in the face of decisions by large conglomerates to close marginally profitable subsidiaries. SENATE COMM. ON SMALL BUSINESS, supra note 3, at iv. In the last decade alone, employees have purchased an estimated fifty companies. Id.

6. Worker-owned firms vary greatly in ownership structure and in the extent of workers' participation in management decisonmaking. See D. ZWERDLING, WORKPLACE DEMOCRACY 5-6 (1980). 
tion in management decisionmaking. The close labor-management ties that result from that participation, ${ }^{7}$ however, may be subject to challenge under section 8(a)(2) of the National Labor Relations Act (NLRA), which prohibits employer domination or support ${ }^{9}$ of employee labor organizations. ${ }^{10}$

Most such firms have between one hundred and four hundred employees, SURVEY RESEARCH CENTER, INSTITUTE FOR SOCIAL RESEARCH, UNIVERSITY OF MICHIGAN, EMPLOYEE OWNERSHIP 8-9 (1978), although at least one worker-owned firm numbers its employees in the thousands, see Thomson, supra note 1, at 7-8 (discussing Chicago and Northwestern Transportation Company, with 3400 employee shareholders out of 14,000 employees). Most worker-owned firms, particularly those organized as cooperatives, have fewer members for two reasons. First, size beyond a certain point strains workers' ability to raise the capital necessary to buy and operate a major factory or corporation. Second, a large number of worker-owners may impede efforts to share management authority, at least in cooperatives where many important decisions are made collectively. See K. BERMiAN, WORKER OWNED PLYWOOD COMPANIES 204-05 (1967).

The firms produce a large variety of products, see D. ZWERDLING, supra, at 53-79, 95-104 (describing variety of worker-owned firms), and appear most often in labor-intensive industries, see $\mathrm{K}$. BERMAN, supra, at 205. This concentration in labor-intensive industries has been explained as a result of the increased productivity often associated with worker-ownership, see Olympia Veneer Co. v. Comm'r, 22 B.T.A. 892, 901 (1931) (high wages to shareholders in plywood companies constitute reasonable compensation because of greater productivity of worker-owners); SENATE COMM. ON SMALL BUSINESS, supra note 3, at 18 (worker-owned firms generally have higher profits and greater productivity than comparable firms), although some commentators question whether worker ownership does in fact lead to greater productivity, see O'Toole, The Uneven Record of Employee Owner. ship, 57 Harv. BUS. REV., Nov.- Dec. 1979, at 190; Ross, supra note 4, at 109. Among those who believe that worker-owned firms are more productive, some attribute the improved productivity to employees' recognition that they are working for themselves, of. D. ZWERDLING, supra, at 100 (worker-owners in plywood companies attribute impressive productivity to financial and emotional involvement in their companies), while others contend that increased productivity is primarily attributable to increased participation, see C. BELLAS, INDUSTRIAL DEMOCRACY AND THE WORKER-OWNED FIRM 29, 35-40 (1972); Long, Share Ownership Versus Control, 31 HUM. REL. 753, 755 (1978); W. Whyte, From Private to Employee Ownership: Notes for Transforming the Shut Down Plant 11 (Nov. 1976) (unpublished paper on file with Yale Law Journal).

7. See Gurdon, supra note 2, at 299-300 (worker ownership may lead to unusually active employee-management cooperation).

8. National Labor Relations (Wagner) Act, 29 U.S.C. $§ \S 151-169$ (1976) [hereinafter cited as NLRA]. Section $8(a)(2)$ provides, in relevant part:

(a) It shall be an unfair labor practice for an employer . . . (2) to dominate or interfere with the formation or administration of any labor organization or contribute financial or other support to it: Provided, That . . . an employer shall not be prohibited from permitting employees to confer with him during working hours without loss of time or pay ....

29 U.S.C. $\$ 158(\mathrm{a})(2)(1976)$.

9. Charges of employer domination or support may be lodged under the general prohibitions of section 8(a)(1), as well as under the more specific proscriptions of section 8(a)(2). See, e.g., Dennison Mfg. Co., 168 N.L.R.B. 1012, 1013 (1967). Section 8(a)(1) provides: "It shall be an unfair labor practice for an employer-(1) to interfere with, restrain, or coerce employees in the exercise of their rights guaranteed in section 157 of this title." 29 U.S.C. $\$ 158(a)(1)(1976)$. Section 8(a)(1)'s general prohibition of interference includes but is not limited to all of the types of conduct specifically proscribed in paragraphs (2) through (5) of section 8(a). 42 NLRB ANN. REP. 75 (1977). Subsequent references to section $8(a)(2)$ should be read as including section $8(a)(1)$.

The appropriate remedy for a violation of section $8(a)(2)$ depends on the degree of employer assistance. After a finding of domination, an employer is ordered to disestablish and cease dealing with the dominated organization. After a finding of unlawful support, however, an employer is ordered only to cease dealing with the supported organization, unless that organization is subsequently certified by the National Labor Relations Board (NLRB) in a new representation election as the collective bargaining representative of the employees. 14 NLRB ANN. REP. 57 (1950).

10. Section $2(5)$ of the NLRA defines a labor organization as 


\section{Worker Ownership}

This Note examines the problem posed for worker-owned firms by a labor relations statute that contemplates a traditional adversary labormanagement relationship. The Note suggests that shared labor-management interests, and the extent of worker participation in management possible in worker-owned firms, make conventional section 8(a)(2) analysis inappropriate in the worker-ownership context. To grant worker-owned firms organizational flexibility consistent with the NLRA's primary purpose of promoting industrial peace, ${ }^{11}$ the Note proposes an amendment to section 8(a)(2) that would permit management involvement with employee labor organizations in certain worker-owned firms. The Note concludes by suggesting criteria to assist courts and the National Labor Relations Board (NLRB) in determining which worker-owned firms should not be subject to judicial or administrative intervention under section $8(a)(2)$ as amended.

I. The Phenomenon of Worker Ownership and the Policy of Section $8(a)(2)$

Worker-owned firms differ greatly in organization and operation, ranging from democratically managed producer cooperatives to more traditionally supervised corporations. Current interpretations of section 8(a)(2), however, may unnecessarily restrict the freedom of employee-owners to experiment with innovative labor-management structures for their firms.

\section{A. Patterns of Worker Ownership}

The two main ways of structuring worker-owned firms are by means of producer cooperatives and employee stock ownership plans. Producer cooperatives, although relatively few in number, ${ }^{12}$ are among the most democratic of worker-owned firms. ${ }^{13}$ In most producer cooperatives, each employee $^{14}$ owns one share of stock and exercises one vote in shareholder

any organization of any kind, or any agency or employee representation committee or plan, in which employees participate and which exists for the purpose, in whole or in part, of dealing with employers concerning grievances, labor disputes, wages, rates of pay, hours of employment, or conditions of work.

29 U.S.C. $\S 152(5)$ (1976).

Employer attempts to escape the strictures of section $8(a)(2)$ by claiming that a challenged employee labor organization does not fall within the definition of section 2(5) almost never succeed. See Note, Section 8(a)(2): Employer Assistance to Plant Unions and Committees, 9 STAN. L. REV. 351, 352-54 (1957); infra note 57.

11. See NLRB v. Fansteel Metallurgical Corp., 306 U.S. 240, 257 (1939); NLRA § 1, 29 U.S.C.

$\S 151$ (1935); 79 CONG. REC. 7573 (1935) (remarks of Senator Wagner).

12. See SENATE COMM. ON SMALL BUSINESS, supra note 3, at 13.

13. Producer cooperatives are best exemplified by a group of worker-owned plywood companies located in the Pacific Northwest. For detailed analyses of those companies, see C. BELLAS, supra note 6; K. BERMAN, supra note 6.

14. The term "employee" as used in this Note includes nonshareholders as well as shareholders, 
referendums. Final authority over the company rests with the collective membership, and all profits not reinvested in the firm are divided equally among the employee-owners, regardless of which job an owner performs. ${ }^{15}$ Employee shareholders elect fellow shareholders to a board of directors, ${ }^{16}$ and the board in turn retains a general manager to supervise the daily operations of the company. ${ }^{17}$ Stockholder committees often handle various special problems, such as plant expansion or employee grievances. ${ }^{18}$ The board of directors and individual shareholders are consulted by retained management and participate in management decisions to a greater degree than is usual in a traditionally owned firm. ${ }^{19}$

Producer cooperatives are not free from labor strife. ${ }^{20}$ Workers frequently disagree with decisions made by retained managers and governance committees, particularly on matters of company investment and employee pay. ${ }^{21} \mathrm{~A}$ few worker-owned cooperatives are unionized, ${ }^{22}$ and management-union relations in these firms are not always amicable..$^{23}$

Most worker-owned firms are characterized by a less broadly based form of ownership effected through "Employee Stock Ownership Plan" trusts, ${ }^{24}$ or through the direct purchase by some workers of varying

but does not include supervisory personnel. The term "worker" is used here synonyomously with "employee," and the terms "worker-owners" and "employee-owners" are used interchangeably to indicate shareholder employees.

15. See K. BERMAN, supra note 6 , at 8 . In practice, most cooperatives depart somewhat from this pattern. Many of the plywood cooperatives, for example, hire some nonshareholder employees, often to handle especially unappealing jobs. Only in extreme cases, however, does the ratio of nonshareholders to shareholders become so high that the company loses its identity as a cooperative. Id. at 148-50, 155.

16. Id. at 157.

17. The general manager may be a shareholder or may be hired from outside the company. Id. at 158.

18. Id. at 157.

19. Id. at $158-59$

20. See id. at 124-28 (friction with unions often occurs in worker-owned firms taken over from conventional companies); Shirom, The Industrial Relations Systems of Industrial Cooperatives in the United States, 1880-1935, 13 LAB. HIST. 533, 547-48 (1972) (accounts of internal dissension in industrial cooperatives).

21. See C. BELLAS, supra note 6, at 29 (employee-shareholders often reluctant to approve decisions that require retention and reinvestment of earnings).

22. See SENATE COMM. ON SMALl BUSINESS, supra note 3, at 11-12; cf. D. Ellerman, The Union as the Legitimate Opposition in an Industrial Democracy 5-12 (Dec. 1979) (unpublished paper on file with Yale Law Journal) (unions still needed in worker-owned firms to act as "Ioyal opposition" to management). Most members of producer cooperatives feel little need for unions, however, since the ability of workers to participate in management decisions enables them to seek better wages and working conditions on their own. See P. BERNSTEIN, WORKPLACE DEMOCRATIZATION 22 (1976).

23. See K. BERMAN, supra note 6, at 124-28 (history of plywood cooperatives' relations with labor organizations). In at least one case, a strike by nonshareholder employees caused the temporary collapse of a newly organized cooperative. Id. at 127-28.

24. Employee Stock Ownership Plans (ESOPs) are governed by parallel provisions of the labor law and the Internal Revenue Code. See Employee Retirement Income Security Act of 1974 (ERISA), 29 U.S.C. $§ \S 1001-1381$ (1976 \& Supp. III (1979)); I.R.C. § 4975 (1976 \& Supp. III 1979)). ESOPs serve a wide variety of purposes. Under a typical ESOP, as used in the worker ownership context, a corporation sets up an employee trust that borrows investment capital to purchase 


\section{Worker Ownership}

amounts of company stock. ${ }^{25}$ In such firms, individual employee ownership interests vary. In some, management controls a majority of the stock ${ }^{26}$ and runs the company as it would a traditionally owned firm, making few efforts to increase worker participation in the decisionmaking process. ${ }^{27}$ In others, workers own and vote a majority of company stock and elect representatives to a board of directors. ${ }^{28}$ Even then, however, some employees may not have a significant voice in management decisions. ${ }^{29}$

Even when production workers buy a majority of company stock, management personnel often refuse to share decisionmaking responsibilities with workers. ${ }^{30}$ Conflicts of interest may arise when some members of

company stock. The corporation then makes periodic payments to the trust, and the payments are used to repay the original loan and release stock from the trust to individual employees. See S. REP. No. 93, 96th Cong., 1st Sess. 5 (1979). Since corporate contributions to the trust are tax deductible, many corporations-as many as 4000 according to a recent estimate-use ESOPs as an inexpensive means of raising investment capital. See Ross, supra note 4, at 109 . Only rarely do ESOPs afford employees majority ownership, and even then, voting restrictions placed on the stock may prevent employees from exercising effective control over the company. See id.; D. ZWERDLING, supra note 6, at 67. See generally Stern \& Comstock, Employee Stock Ownership Plans (ESOPs): Benefits for Whom? 23 KEY ISSUES 35-42 (1978).

25. About one-fourth of existing employee-owned companies were formed by direct employee purchases of company stock. SENATE COMM. ON SMALL BUSINESS, supra note 3, at 13. Direct stock purchases are relatively recent phenomena and occur primarily when workers seek to buy a company that would otherwise close or relocate. Id.

26. South Bend Lathe, Inc., a machine tool manufacturer located in South Bend, Indiana, is typical of such firms. South Bend Lathe was the first employee-owned company to be acquired wholly by means of an Employee Stock Ownership Plan. In 1980, workers exercised voting control over $16 \%$ of the company's stock, with management-appointed trustees voting the remainder. Workers have one representative, a union official, on the board of directors, and an employee committee meets monthly with the firm's president to discuss aspects of the business not considered "strictly confidential." $D$. ZiWERDLING, supra note 6, at 66-70; Ross, supra note 4, at 109-10. By 1985, production workers are scheduled to control $66 \%$ of the company's stock and will probably participate more actively in management decisions. D. ZWERDLING, supra note 6 , at 70.

27. A recent study indicates that employees in worker-owned firms "influence "important decisions" "in $51 \%$ of companies with ESOPs and $77 \%$ of companies with direct ownership. SURVEY RESEARCH CENTER, supra note 6, at 20.

28. On average, workers are represented on the board of directors in $36 \%$ of companies with ESOPs and 77\% of companies with direct ownership. Id.

29. The history of the Vermont Asbestos Group, as narrated in D. ZwERDLING, supra note 6, at $53-62$, illustrates some of the problems encountered by workers even in a financially successful worker-owned firm. Initially, workers controlled $78 \%$ of the company's stock and elected a fifteenmember board of directors composed of seven hourly workers, seven management representatives, and a state official. Most important decisions, however, were made by the same top management officials who ran the company before it became worker-owned.

The mine prospered under its new ownership, and production workers netted a $19.4 \%$ increase in wages and benefits after the first year. Gradually, however, workers began to seek greater infuence in management decisions. In 1978, after management decided to establish a subsidiary wallboard company, a majority of workers voted against the proposal. The worker-elected board of directors, however, ignored the vote. Management and production workers became increasingly estranged, and the union almost launched a strike when its wage demands were not met. Eventually, workers voted to accept, at a substantial profit, the tender offer of a local businessman for a controlling block of the company's stock.

30. Gurdon, supra note 2, at 303; see O'Toole, supra note 6, at 193 (most managers in workerowned firms unwilling to change labor-management responsibilities in response to altered patterns of ownership). 
worker-owned firms, primarily management personnel, possess disproportionately large stock interests; ${ }^{31}$ employee ownership may then serve simply to reinforce management's traditional status. ${ }^{32}$ The resulting frustration of worker-owners' expectations of heightened influence in decisionmaking may cause a return to traditional adversary labor-management relations and may encourage an unusually aggressive union stance during collective bargaining. ${ }^{33}$ As both management and labor gain more experience with worker ownership, however, they may learn to avoid such difficulties. ${ }^{34}$

\section{B. Section 8(a)(2) Doctrine and Worker-Owned Firms}

Section $8(a)(2)$ of the NLRA is designed to protect the freedom of employees to choose the form of organization and collective action that best suits their interests in dealing with management. ${ }^{35}$ Judicial interpretation of section 8(a)(2) has evolved from an initial belief that free choice requires nearly total insulation of employee labor organizations from management to a recognition that it permits a degree of "cooperation" between management and workers' organizations. ${ }^{36}$ Yet even this recent, more expansive, interpretation of section 8(a)(2) may significantly impair the freedom of employee-owners to participate in management decisions.

31. Managerial employees tend to acquire disproportionately large stock interests in firms with ESOPs, because stock in such firms is usually distributed in proportion to salary. SENATE COMM. ON SMALL BUSINESS, supra note 3, at 4. Similarly, higher salaries often enable managerial employees to dominate worker-owned firms that permit the direct purchase of company stock according to employees' financial capability. Hearings on S.388, supra note 4, at 142 (statement of David Ellerman, economist, Industrial Cooperative Association).

32. See Gurdon, supra note 2 , at 303.

33. Id. at 307. About one-third of employee-owned companies are at least partially unionized. SURVEY RESEARCH CENTER, supra note 6, at 20. The function of these unions varies. In firms that do not provide employees significant opportunities for participation in management, unions tend to play a traditional adversary role. See W. Whyte, Making the Breaks at Rath 9-10 (1980) (unpublished paper on file with Yale Law Journal); supra note 29 (history of Vermont Asbestos Group). In firms that provide workers with significant influence on management decisions, most notably producer cooperatives, unions may be unnecessary. See infra note 85 .

34. Professor Gurdon suggests several ways to lessen problems stemming from the frustration of employee-owners' expectations of shared management authority, such as a two-class system of common stock designed to guarantee equal voting rights to all members of an employee-owned organization. Gurdon, supra note 2, at 306-07.

35. See H.R. REP. No. 1147, 74th Cong., 1st Sess. 18 (1935). As the Supreme Court observed in one early decision, a critical question in section $8(\mathrm{a})(2)$ cases is whether an employee organization exists as the result of the employees' free choice, or as the result of an employer's intrusion. NLRB v. Linkbelt Co., 311 U.S. 584, 587-88 (1941). Lower courts have often stressed this goal of employee free choice. See, e.g., NLRB v. Wemyss, 212 F.2d 465, 471-73 (9th Cir. 1954).

36. See Note, New Standards for Domination and Support Under Section 8(a)(2), 82 YALE L.J. $510,511-25$ (1973) (discussing evolution of section 8(a)(2) doctrine). Compare NLRB v. Newport News Shipbuilding \& Dry Dock Co., 308 U.S. 241, 251 (1939) (management involvement with employee labor organization unlawful despite employee satisfaction and absence of labor strife within company) with Chicago Rawhide Mfg. Co. v. NLRB, 221 F.2d 165, 167 (7th Cir. 1955) (courts must distinguish between unlawful employer domination of labor organization and desirable labor-management cooperation). 


\section{The Traditional Approach to Section 8(a)(2)}

The traditional enforcement doctrine for section 8(a)(2) emerged in 1939 with the Supreme Court's decision in NLRB v. Newport News Shipbuilding \& Dry Dock Co. ${ }^{37}$ In that case, the Court ordered the disestablishment of an employee labor organization, despite the employees' apparent satisfaction with its representation of their interests: ${ }^{38}$ In ensuing years, lower courts and the NLRB developed a virtual per se rule invalidating almost any form of employer assistance to employee labor organizations, and proscribing most management efforts to share policy responsibilities with employee groups. ${ }^{39}$

By the 1950's, however, the demise of the company union, ${ }^{40}$ the growth of organized labor, ${ }^{41}$ and the decline in industrial warfare led many courts to vary from the strict adversarial interpretation of section 8(a)(2) advanced in Newport News Shipbuilding. ${ }^{42}$ In 1955, the Seventh Circuit announced a less rigid interpretation of section 8(a)(2) in Chicago Rawhide Manufacturing Co. v. NLRB. ${ }^{43}$ Although the Chicago Rawhide court reaffirmed the long-established principle that section $8(\mathrm{a})(2)$ proscribes any employer influence over employee labor organizations, it also held that in order to further the NLRA's goal of promoting labor-management cooperation, acceptable cooperation had to be distinguished from imperinissible support. The court therefore reversed an NLRB directive disestablishing an employee association formed jointly by the management of the company and its employees. ${ }^{44}$

37. 308 U.S. 241 (1939).

38. Id. at 251.

39. See Note, supra note 36 , at $511-14$ (discussing per se rule cases); Note, supra note 10 , at 354 60 (strict "hands-of" approach required of employer).

40. See Note, supra note 36 , at 515-16.

41. In the 1940's, the widespread public sympathy enjoyed by the union movement during the preceding decade began to decline. M. DERBER, THE AMERICAN IDEA OF INDUSTRIAL DEMOCRACY, 1865-1965, at 430-31 (1970). Public policy also changed, as Congress became more concerned with regulating unions than with protecting them. See Note, supra note 36, at 516. Thus in 1947, Congress specified a list of union unfair labor practices comparable to the employer unfair labor practices set forth in the NLRA. Labor Management Relations (Taft-Hartley) Act, Pub. L. No. 80-101, 61 Stat. 136 (1947) (codified at 29 U.S.C. $\$ \S 141-197$ (1976)). In 1959, Congress first regulated the internal structure of unions. Labor Management Reporting and Disclosure (Landrum-Griffin) Act, Pub. L. No. 86-257, 73 Stat. 519 (1959) (codified at 29 U.S.C. $\$ \S 401-531$ (1976)).

42. In NLRB v. Valentine Sugars, Inc., 211 F.2d 317 (5th Cir. 1954), a forerunner of later "cooperation" cases, the Fifth Circuit expressly rejected the view that the NLRA reflects a class conflict ideology. Focusing on the Act's larger aim of promoting "amity and cooperation," while largely ignoring the Act's adversarial presuppositions, the court concluded that "courtesies" extended by management to union members were not indicative, by themselves, of unlawful employer support. Id. at 320-21.

43. 221 F.2d 165 (7th Cir. 1955).

44. The court's decision explicitly noted the NLRB's conclusion that similar employee representation plans had been routinely struck down in the past. Id. at 167. Nonetheless, the court found that in this instance the NLRB had confused cooperation with support. The court's distinction between permissible and impermissible employer activity is tenuous at best: support is defined as employer actions 
Other courts have since held that the NLRA is designed to encourage labor-management cooperation and that the distinction between domination and cooperation is important to that design..$^{45}$ Courts adopting such an interpretation refuse to disestablish a labor organization absent evidence of actual employer domination or support ${ }^{46}$ that exceeds mere cooperation and enters into the "proscribed domain of interference." ${ }^{17}$ Under this view, many employer actions once considered virtual per se violations of section $8(a)(2)^{48}$ may no longer by themselves justify a finding of prohibited domination or support. ${ }^{49}$

Nonetheless, the Chicago Rawhide cooperation approach does not obviate the need for an amendment to section 8(a)(2). First, the notion of cooperation is a vague one. Acts that considered individually might constitute cooperation together may be considered unlawful domination. $.^{50} \mathrm{Vir}-$ tually all the factors that have prompted courts to invoke section 8(a)(2) in the past are still relevant in assessing whether employer-employee "cooperation" efforts cross the uncertain line between legitimate and illegiti-

exerting some degree of influence or control; cooperation is described as employer actions that only assist employes in carrying out their independent intentions. Id.

45. See, e.g., NLRB v. Northeastern Univ., 601 F.2d 1208, 1214 (1st Cir. 1979) (given changing conditions, cooperative employer-employee arrangements justified as alternative to traditional adversary relations); Federal Mogul-Corp. v. NLRB, 394 F.2d 915, 918 (6th Cir. 1968) (cooperation does not amount to support unless it hinders employees' freedom of choice); NLRB v. Post Publishing Co., 311 F.2d 565, 569 (7th Cir. 1962) (cooperation is desirable objective under NLRA). As the Ninth Circuit has observed, section $8(a)(2)$ read literally would bar any form of employer-employee cooperation, and by so doing, would frustrate the NLRA's aim of allowing employees freedom of choice in selecting their bargaining representative. Hertzka \& Knowles v. NLRB, 503 F.2d 625, 630 (9th Cir. 1974), cert. denied, 423 U.S. 875 (1975).

46. See, e.g., NLRB v. Northeastern Univ., 601 F.2d 1208, 1213 (1st Cir. 1979) (actual, not potential, domination must be found before disestablishment); Federal-Mogul Corp. v. NLRB, 394 F.2d 915, 918 (6th Cir. 1968) (potential for employer domination inheres in employer-employee relationship, but only actual domination is unlawful); Coppus Eng'g Corp. v. NLRB, 240 F.2d 564, 573 (1st Cir. 1957) (even employee committee lacking independence from employer should not be disestablished absent evidence of actual domination).

47. NLRB v. Keller Ladders, 405 F.2d 663, 667 (5th Cir. 1968); accord, NLRB v. Vernitron Elec. Components, Inc., 548 F.2d 24, 26 (1st Cir. 1977) (court must determine whether employer conduct exceeds cooperation-interference boundary); NLRB v. Prince Macaroni Mfg. Co., 329 F.2d 803, 811 (1st Cir. 1964) (although not actually dominating employee labor organization, employer overstepped line between cooperation and support by organizing and supervising employee committee elections).

48. See Note, supra note 36 , at 512 (listing examples of once per se illegal employer assistance). 49. See, e.g., NLRB v. Northeastern Univ., 601 F.2d 1208, 1213 (1st Cir. 1979) (employer's payment of employee committee expenses does not constitute domination); NLRB v. Magic Slacks, Inc., 314 F.2d 844, 847 (7th Cir. 1963) (employer's permission for union to use company time and premises does not amount to assistance and support).

50. District 65, Distributive Workers of Am. v. NLRB, 593 F.2d 1155, 1161 (D.C. Cir. 1978) (acts considered individually might constitute cooperation, but courts must consider them in aggregation; pattern of employer assistance may imply that union's majority support is "tainted"); Hesston Corp., 175 N.L.R.B. 96, 103 (1969) (thin line between cooperation and support, but even innocent support may be unlawful); see 2 NLRB ANN. REP. 95 (1937) (section 8(a)(2) violations found when acts "in their totality constitute domination or interference with a labor organization"). 
mate support. ${ }^{51}$ The Chicago Rawhide approach has simply raised the threshold showing of employer involvement necessary to sustain an unfair labor practice charge. Finally, the NLRB has not clearly adopted the cooperation approach. In one recent case, for example, the Board ruled that an employer's provision of company facilities to an employee-initiated committee violated section $8(a)(2)$ even though the Board found that the "parties dealt at arm's length and in a manner similar to a legitimate collective bargaining relationship." 52

\section{Application of Conventional Doctrine to Worker Ownership}

Without further refinement, even a liberal interpretation of section $8(a)(2)$ may restrict greatly the freedom of worker-owners to experiment with new structures capable of responding to the unusual pressures and opportunities for labor-management interaction that exist in many worker-owned firms. In many such firms, the traditional distinctions between management and labor blur. ${ }^{53}$ Frequently, active union support is a prerequisite to the initial purchase of a plant on the verge of liquidation by its corporate owner. ${ }^{54}$ Union members and officials often become part owners of the new enterprise, sometimes participating in its management and serving on its board of directors. ${ }^{55}$ Since union representatives on a board may adopt management positions, ${ }^{56}$ it is hard under such circum-

51. The criteria considered by courts and the NLRB as evidence of domination or support in 1980, see GUIDEBOOK TO LABOR RELATIONS (CCH) 153-54 (1980), are strikingly similar to the criteria considered significant shortly after the NLRA was passed, see 3 NLRB ANN. REP. 113 (1938).

Little consistency is to be found in decisions of courts or the NLRB as to the precise location of the cooperation-support boundary. See NLRB v. Vernitron Elec. Components, Inc., 548 F.2d 24, 26 (1st Cir. 1977) (support-cooperation boundary difficult to mark precisely); Longchamps, Inc., \& Local 650, Chain Restaurant Employees Union, 205 N.L.R.B. 1025, 1031 (1973) (same). Some courts pay particular attention to evidence of employee satisfaction or employer intent. See Chicago Rawhide Mfg. Co. v. NLRB, 221 F.2d 165, 170 (7th Cir. 1955); Note, supra note 36, at 520-25. Other courts find neither criterion controlling. See NLRB v. Vernitron Elec. Components, Inc., 548 F.2d 24, 26 (1st Cir. 1977). That imprecision sometimes leads to opposite results despite similar facts. Compare Columbus Janitor Serv., 191 N.L.R.B. 902 (1971) (management's efforts to persuade employees to choose one labor organization over another held unlawful) and Greystone Knitwear Corp., 136 N.L.R.B. 573 (1962), affd, 311 F.2d 794 (2d Cir. 1963) (same) with Coamo Knitting Mills, Inc., 150 N.L.R.B. 579 (1964) (similar management preference shown one labor organization over another held permissible) and Jolog Sportswear, Inc., 128 N.L.R.B. 886 (1960) (same), petition dismissed sub. nom. Kimbrell v. NLRB, 290 F.2d 799 (4th Cir. 1961).

52. See American Tara, 242 N.L.R.B. 1230 (1979).

53. This is especially true of cooperatives, in which directors are also working stockholders. See $\mathbf{P}$. Pitegoff, Unions and Workers' Cooperatives: Labor Law Implications 7-8 (Jan. 15, 1980) (unpublished paper on file with Yale Law Journal).

54. See Stern \& Hammer, supra note 4, at 1113; W. Whyte, supra note 33, at 9.

55. See Thomson, supra note 1 , at 12 .

56. A dramatic example of this phenomenon occurred at the worker-owned Vermont Asbestos Group, when worker representatives on the board of directors approved a management proposal in direct defiance of a vote by fellow workers. See supra note 29 . At the worker-owned South Bend Lathe company, described in supra note 26 , one union official resigned from the board of directors 
stances to attribute true arms-length, adversarial bargaining to labor-management relations. ${ }^{57}$ Employee stock ownership accentuates the problem, for actions likely to benefit workers at the company's expense may be contrary to the ownership interests of union shareholders. ${ }^{58}$

In addition to the blurring of traditional labor-management distinctions, differing employee ownership interests may create inherent conflicts of interest even among employee-owners with identical jobs. ${ }^{59}$ Employees with significant stock holdings, for example, may wish to reinvest earnings in the company, while workers with smaller holdings may wish to receive all earnings in the form of wages. ${ }^{60}$ Similarly, employees afforded long-term

because he felt he could not simultaneously represent both labor and management; another union official remained on the board, but admitted that working with management had "moderated" his views. See D. ZWERDLING, supra note 6, at 70, 173.

Labor leaders have long feared that conflicting loyalties stemming from union participation in management decisions or from union representation on corporate boards might undermine the traditional role of unions as adversarial counterweights to management power. See D. ZWERDLING, supra note 6, at 172-74; Summers, Worker Participation in the U.S. and West Germany: A Comparative Study from an American Perspective, 28 AM. J. COMP. L. 367, 370-71 (1980).

57. Problems of interdependence may also arise in nonunionized worker-owned firms, at least in those firms in which management attempts to provide employees a voice consistent with their ownership holdings. As in unionized firms, the independence of worker representatives serving on the board of directors may be called into question. In addition, nonunionized employee-owned companies may attempt to govern by means of in-plant employee-management committees. See K. BERMAN, supra note 6 , at 157 . Yet employee committees sharing management responsibilities may prove especially susceptible to charges of domination and support. See Note, Does Employer Implementation of Employee Production Teams Violate Section 8(a)(2) of the National Labor Relations Act? 49 IND. L.J. 516, 531-36 (1974); Note, The West German Model of Codetermination Under Section 8(a)(2) of the NLRA, 51 IND. L.J. 795, 812-13 (1976). Under the conventional approach to section 8(a)(2), extensive employer involvement with such committees almost invariably results in findings of unlawful domination or support. See, e.g., Ed Taussig, Inc., 108 N.L.R.B. 470,476 (1954) (employer support for employee management committee violates section $8(a)(2)$ even though insubstantial and in good faith). But see Hertzka \& Knowles v. NLRB, 503 F.2d 625, 631 (9th Cir. 1974), cert. denied, 423 U.S. 875 (1975) (employee-initiated labor-management committees are permissible absent evidence of employee dissatisfaction).

58. See Long, supra note 3, at 47 (employees hesitate to strike against company in which they have invested). Employees in some worker-owned firms may be willing to accept wage and benefit reductions, the introduction of labor-saving machinery, and stricter job discipline if their firm encounters financial difficulties. See K. BERMAN, supra note 6, at 186-87; cf. Gurdon, supra note 2, at 302 (employee-ownership generates greater job satisfaction, greater commitment to company, and greater anti-union sentiment).

59. These conflicts may pose further problems for worker-owners under the judicial doctrine of fair representation, which requires a union to represent fairly all employees in a bargaining unit. As developed in the cases, a union or other bargaining representative is permitted "[a] wide range of reasonableness . . . subject always to complete good faith and honesty of purpose in the exercise of its discretion." Ford Motor Co. v. Huffman, 345 U.S. 330, 338 (1953). See generally Summers, The Individual Employee's Rights Under the Collective Agreement: What Constitutes Fair Representation? 126 U. PA. L. REV. 251 (1977). This minimum standard of good faith may be difficult to satisfy if some union members or officers have a financial stake in the company that predisposes them to a particular position.

For similar reasons, it also may be difficult to determine the appropriate bargaining unit in a worker-owned company. Cf. NLRB v. Fort Vancouver Plywood Co., 604 F.2d 596, 600 (9th Cir. 1979), cert. denied, 445 U.S. 915 (1980) (difficult to draw line between shareholder "workers" and nonshareholder "employees").

60. See supra p. 618 (problems caused by desire of some workers to convert most profits into wages); supra note 29 (conflict over management proposal to use surplus funds to build new factory). 
security through share ownership may oppose a pension plan desired by employees with smaller ownership interests. ${ }^{61}$

Some courts may be sufficiently influenced by the unusual characteristics of worker-owned firms to permit a considerable degree of employer assistance to labor organizations formed by employee-owners. The language used in some decisions upholding management-assisted labor organizations suggests that a significant amount of assistance may be acceptable, as long as it can be demonstrated that employees are satisfied and that management is not manipulating employees' choice of a bargaining representative. ${ }^{62}$ In practice, however, courts are unlikely consistently to adopt such an expansive view of section 8(a)(2). Even under liberal interpretations of traditional section $8(a)(2)$ doctrine, the absence of armslength bargaining often serves as the basis for a finding of unlawful domination or support, especially if coupled with traditional indicia of prohibited interference, such as the provision of company premises ${ }^{63}$ or the presence of management representatives at union meetings. ${ }^{64}$ Such findings may be even more likely in light of the fact that a degree of labor-management cooperation exists in many worker-owned firms that is greater than the degree courts have thus far recognized as acceptable.

In addition, both Congress and the Supreme Court have indicated their disapproval of owner- or management-assisted labor organizations under the current NLRA. In 1947, Congress explicitly rejected a proposed amendment that would have permitted employer-initiated and -assisted labor organizations when employees did not themselves designate a bargaining representative. ${ }^{65}$ Similarly, in 1959 the Supreme Court in NLRB v.

61. Cf. D. ZWERDLING, supra note 6, at 70 (older employees at worker-owned company unable to accumulate sufficient stock equity in company to match lost pension rights).

62. See supra pp. 621-22 (courts that apply liberal interpretation of section $8(a)(2)$ are strongly influenced by evidence of employee satisfaction and employer good faith); Note, supra note 36, at 519 . 25 (proposing employer intent and employee satisfaction as standards for evaluating section $8(a)(2)$ complaints).

63. The NLRB regarded union use of company premises as evidence of section 8(a)(2) violations in 125 of the 136 cases involving that issue considered between 1950 and 1974 . Kesselring \& Brinker, Financial and Material Support Under Section 8(a)(2), 31 LAB. L.J. 3, 6 (1980).

64. Active involvement of supervisory personnel in union affairs led to findings of unlawful domination in 86 of the 107 NLRB cases considering that issue that arose between 1950 and 1974. Kesselring \& Brinker, Employer Domination Under Section 8(a)(2), 30 LAB. L.J. 340, 343 (1979). In some cases, the NLRB ruled that the involvement of supervisory personnel in employee labor organizations, though not per se evidence of domination, did constitute evidence of unlawful support. Id. at 346 .

65. The proposed amendment read in part:

(d) Notwithstanding any other provisions of this section, the following shall not constitute or be cvidence of an unfair labor practice under any of the provisions of this Act: (3) [f]orming or maintaining by an employer of a committee of employees and discussing with it matters of mutual interest, including grievances, wages, hours of employment, and other working conditions, if the Board has not certified or the employer has not recognized a representative as their representative under section 9.

H.R. 3020, 80th Cong., 1st Sess., $\S 8$ (d)(3) (1947), reprinted in 1 NLRB, LEGISLATIVE HISTORY OF THE LABOR-MANAGEMENT RELATIONS ACT 31, 56 (1948). For a discussion of the significance of this 
Cabot Carbon Co. ${ }^{66}$ rejected the notion that employer-assisted committees were somehow exempt under the Taft-Hartley Act from section 8(a)(2)'s proscription of domination and support. ${ }^{67}$ Accordingly, even courts willing to permit a considerable degree of management involvement in labor organizations under current doctrine nonetheless must recognize that section 8(a)(2) prohibits employer involvement in employee labor organizations beyond a certain critical level. Some worker-owned firms, by placing worker representatives on boards of directors, forming employee-management governance committees, and undertaking other forms of employee participation in management, have moved far beyond that level.

As worker-owners experiment with new structures for labor-management interaction, the degree of management assistance is likely to increase, further exceeding levels found acceptable under current doctrine. If a disgruntled employee or a competing union decides to challenge the structure of labor-management relations in a worker-owned firm, courts and the NLRB might impose conventional section 8(a)(2) sanctions and thereby greatly circumscribe the freedom of employee-owners to participate in management. By greatly restricting employer involvement in labor organizations, the traditional domination or support doctrine could thus unnecessarily limit efforts to increase employee participation in management decisionmaking, even when extensive employee participation is the most efficient way to run a firm. ${ }^{68}$ The proscription of joint labor-management committees may deny employees an opportunity to influence important areas of company policy that fall outside the traditional scope of collective bargaining, including investment and other entrepreneurial decisions. ${ }^{69}$ Limitations on employee participation may also discourage vital union support for the formation of a worker-owned firm. ${ }^{70}$ If a union actively assists in the purchase of an employee-owned company, and later becomes extensively involved in its management, a finding of unlawful domination might permanently prohibit that union from continuing to represent the company's employees, even if the employees want to maintain the union

proposed amendment, see Note, supra note 36 , at 525-27.

66. 360 U.S. 203 (1959).

67. Id. at 217.

68. Cr. Hearings on $S$. 388 , supra note 4 , at 120 (worker participation in management essential to maintenance of efficient employee-owned firm).

69. An employer is legally bound to bargain with a union about "wages, hours, and other terms and conditions of employment." 29 U.S.C. $\$ 158(\mathrm{~d})$ (1976). Although outer boundaries delimiting the subjects that fall within this statutory duty to bargain are not clear, the duty does not reach decisions "which are fundamental to the basic direction of a corporate enterprise or which impinge only indirectly upon employment security." Fibreboard Paper Prods. Corp. v. NLRB, 379 U.S. 203, 223 (1964) (Stewart, J., concurring). Thus an employer is free to decide unilaterally fundamental issues such as the choice of a product line or the sale of the business. See Summers, supra note 56, at 381.

70. Cf. Stern \& Hammer, supra note 4, at 1113 (union support important factor in enabling employees to buy their company); W. Whyte, supra note 33 , at 9 (same). 
as their representative." Thus the implementation of current section 8(a)(2) doctrine in the worker ownership context may frustrate the NLRA's stated goals of promoting industrial peace and employees' freedom of choice.

\section{The Problem of Independence Reconsidered}

The traditional approach to management-employee relations derives from analysis of conventionally owned firms in which ownership and managerial interests are clearly separable from employee interests. That approach does not take into account the greater identity of interests between labor and management possible in a worker-owned firm, or the greater ability of worker-owners to participate in management decisionmaking. As a result, the traditional approach, with its continuing emphasis on preserving the structural independence of employee labor organizations, may unnecessarily frustrate labor-management cooperation in worker-owned firms. Under certain conditions, worker-owners do not need the protections afforded by section 8(a)(2). The NLRA should be amended to provide for that possibility.

\section{A. The Inadequacy of Traditional Section 8(a)(2) Analysis}

Conventional section 8(a)(2) analysis is based on an "adversary" theory of labor relations. ${ }^{72}$ In this view, apparent in the legislative history of the NLRA, ${ }^{73}$ labor and management constitute distinct entities with inherently conflicting interests. ${ }^{74}$ Before the enactment of the NLRA, management occupied the dominant position in labor-management conflicts by reason of its control over workers' jobs. ${ }^{75}$ Proponents of the NLRA argued that the "lone industrial wage earner"

71. See supra note 9 (disestablishment orders accompany findings of unlawful domination).

72. See Note, supra note 36, at 514-15 (adversary model presumes employers have interests antagonistic to interests of employees, and that employers will subvert employee interests given the opportunity). According to one contemporary critic, the Act assumes that most employers are exploiting labor and will do so whenever afforded an opportunity. M. DERBER, supra note 41 , at 358 (citing Paul Litchfield, president of Goodyear Tire and Rubber in 1934).

73. The NLRA was enacted during a period of widespread and often violent industrial turmoil; the Act's legislative history is replete with references to industrial warfare and the "economic struggle or competition between employer and employees as to the share or division between them of the joint product of labor and capital." H.R. REP. No. 1147, supra note 35, at 10 (quoting American Steel Foundries v. Tri-City Cent. Trades Council, 257 U.S. 184, 209 (1921)).

74. Areas of potential conflict between management and labor include "[d]ivision of the returns, quest for security, concepts of responsibility to owners and the public, and survival issues or rivalry for power." D. DE SCHWEINITZ, LABOR AND MANAGEMENT IN A COMMON ENTERPRISE 125 (1949). In a conventional business, gains won by labor in collective bargaining (e.g., increased wages) often represent management losses (e.g., diminished profits). See Ellerman, supra note 22, at 10.

75. See N. CHAMBERLAIN, THE LABOR SECTOR 153 (1965) (NLRA necessary to enable workers to counterbalance management control over jobs).

76. S. REP. NO. 573, 74th Cong., 1st Sess. 3 (1935). 
with an employer unless acting in concert with other employees. ${ }^{71}$ The Act's supporters therefore felt it essential to protect by law the right of employees to organize. ${ }^{78}$ Section 8(a)(2) was included as part of that protection to ensure that once formed, employee labor organizations would not be subject to management influence or control that might undermine their position in an adversarial negotiating process. ${ }^{79}$

The adversary approach to section 8(a)(2) analysis is ill-suited to the worker-ownership context. The presumption of conflicting labor-management interests is not warranted in many worker-owned firms because employee ownership may generate an identity of interests between employer and employees, thereby reducing the bipolar conflict between management and labor that characterizes traditionally owned firms. Improving the economic performance of a worker-owned company directly benefits workers as owners by increasing the value of their share of annual profits. ${ }^{80}$ As workers strive to increase productivity and refrain from actions that might prove detrimental to the company, management may respond in turn by expanding the role of workers in setting company policies. ${ }^{81}$ To the extent that labor-management interests converge, efforts to preserve the separation of management and labor may unnecessarily restrict beneficial labormanagement cooperation.

It is unrealistic, however, to expect the interests of management and labor in a worker-owned firm ever to coincide fully. Issues distinct from the production of profits, such as working conditions, job assignments, and plant discipline, may not fall within the expanded area of shared labormanagement interests generated by employee ownership holdings. ${ }^{82}$ In addition, worker-owners may disagree on the appropriate division of company profits among wages, benefits, and investments. ${ }^{83}$ Even in coopera-

77. See id.

78. See, e.g., H.R. REP. No. 1147, supra note 35, at 16; 79 CONG. REC. $7566-73$ (1935) (remarks of Senator Wagner).

79. See 79 CONG. REC. $7569-73$ (1935) (remarks of Senator Wagner).

80. This convergence of interests appears most clearly in worker-owned cooperatives, in which each worker-shareholder has the same financial stake in the company. See K. BERMAN, supra note 6, at 158-59. A similar convergence between the goals of management and the goals of workers occurs in firms with some sort of economic return to workers apart from wages. According to one commentator, when such an economic return is present, management and labor both "begin to operate more consciously toward the same organizational goal of higher output at lower cost and toward similar personal goals of a satisfying and self-esteemed worklife." P. BERNSTEIN, supra note 22, at 67 (emphasis in original).

81. See P. BERNSTEIN, supra note 22 , at 68 (increased worker attention to company costs alters managers' goals from employee manipulation to joint consultation).

82. Cf. K. BERMAN, supra note 6, at 153-57 (allocation of jobs and plant discipline sometimes sources of friction in plywood cooperatives).

83. See SENATE COMM. ON SMALL BUSINESS, supra note 3, at 12 (workers' desire for take-home pay conflicts with long-term investments recommended by management). 
tives, in which each owner shares equally in company profits, conflicts may arise, if only as to how best to pursue common goals. ${ }^{84}$

In some worker-owned firms, areas of potential conflict may undermine significantly the identity of labor-management interests generated by employee ownership. Whether worker-owners will then need the protection of section $8(a)(2)$, however, depends in large measure on whether worker participation in management is sufficient to offset the inequality in bargaining power that the NLRA was designed to redress. To the extent that workers protect their interests as individual employees through participation in management decisionmaking, there is correspondingly less need for them to organize for collective action to exact concessions from management in adversarial negotiations. ${ }^{85}$ When worker-owners are denied a role in management decisions, labor and management tend to return to their traditional adversary relationship, ${ }^{86}$ and unions tend to play their customary role. ${ }^{87}$

\section{B. Section 8(a)(2) Standards and the Range of Worker-Owned Firms}

Courts that find management assistance to employee labor organizations in worker-owned firms excessive under current section 8(a)(2) analysis may issue cease and desist orders, ${ }^{88}$ regardless of the disruptive effects such orders may have. ${ }^{89}$ In addition to limiting employee participation in the management of the affected firm, the threat of such adverse judicial intervention may deter other worker-owned firms from experimenting with new forms of labor-management cooperation. To avoid unduly constraining worker-owners, courts hearing section $8(a)(2)$ challenges must first recognize the diversity of ownership interests and managerial arrangements in firms under the "worker-owned" rubric.

Producer cooperatives present the clearest case against limiting management-labor interaction. In most such companies, decisionmaking power

84. See C. BELLAS, supra note 6, at 29 (difficult to persuade some workers in plywood cooperatives to take long-range view of possible returns).

85. According to one industrial theorist, unions may be superfuous in worker-owned firms because the primary function of unions-wresting decisionmaking power from the holders of capital- is by definition unnecessary when workers are themselves the holders of capital. P. BERNSTEIN, supra note 22 , at 22 . Where democratization is only partial, however, unions may have an important role to play. Id. at 22; see supra note 22 (employees in producer cooperatives feel little need for unions because they can effectively seek better wages and working conditions on their own).

86. Gurdon, supra note 2, at 307; see Whyte, In Support of Voluntary Employee Ownership, 15 SOCIETY 73, 80 (1978), quoted in Hearings on $S$. 388, supra note 4, at 120 (labor relations strained when employees realize discrepancy between their status as co-owners and their treatment as hired hands).

87. Sec supra p. 620 \& note 33.

88. See supra note 9 (remedies for violations of section $8(a)(2)$ ).

89. See supra pp. $626-27$ (harms to worker-owned firms caused by unnecessary section $8(a)(2)$ sanctions). 
ultimately vests in the entire membership, and the interests of management and labor coincide closely. ${ }^{90}$ Attempts to preserve the independence of employee groups as bargaining entities separate from the employer are therefore unnecessary.

Conversely, conventional section 8(a)(2) standards for intervention are most appropriate for firms in which individual employee ownership interests are minimal and workers do not participate in management. In such cases, the area of shared labor-management interest is not likely to be much greater than in traditional firms, and the relationship between management and labor remains predominantly adversarial despite the employees' financial stake in the company. Without the protection afforded employees by participation in management decisionmaking, the need for independent employee labor organizations, with power to bargain equally with management, remains. ${ }^{11}$ In such firms, the implementation of conventional section $8(a)(2)$ doctrine is appropriate.

The more difficult cases lie between those two extremes. In many worker-owned firms, employees possess both limited ownership interests and limited power over management decisions..$^{92}$ Insofar as labor and management interests diverge in such firms, employee groups must be protected from employer domination under the guise of cooperation. The need for the protection of section 8(a)(2) lessens, however, as the workerowned firm under examination is less like a traditionally owned company and more like a true cooperative.

\section{Amending the National Labor Relations Act}

Since the strictures of section $8(a)(2)$ may in some cases frustrate the interests of employees as worker-owners, the NLRA should be amended to accomodate the unique status of worker-owned firms. An appropriate amendment would exempt worker-owned firms from the requirements of section $8(a)(2)$ to the extent indicated by shared labor-management interests and by worker participation in management. ${ }^{93}$ Such an amendment

90. See supra note 80 (identity of labor-management interests greatest in producer cooperatives).

91. The frustration of employee-owners' expectations of participation in the management of a worker-owned firm may lead to even greater tension in labor-management relations than that found in a similar but traditionally structured firm. See Gurdon, supra note 2, at 304-05.

92. See supra pp. 618-20 (description of worker-owned firms with differing ownership and management structures).

93. Such an amendment should take the following form:

Notwithstanding any other provisions of this section, the following shall not constitute or be evidence of an unfair labor practice under any of the provisions of this Act: Assistance by an employer provided to a labor organization of employee-owners, where employee ownership interests and opportunities for participation in management decisionmaking enable such an assisted labor organization to represent the employees as effectively as could a fully independent labor organization.

This amendment would not require any changes in the definition of terms now found in section 2 of 
would further the underlying purposes of the NLRA by promoting both labor-management cooperation and industrial tranquillity. ${ }^{94}$

Two criteria should govern the implementation of the proposed amendment. These criteria are designed to identify worker-owned firms that do not benefit from the protection of section $8(\mathrm{a})(2)$ and that therefore should be exempt from its restrictions. The amendment and the criteria permit judicial or administrative intervention in only those worker-owned firms in which the benefits of employee ownership are reduced to the mere possession of a financial investment. ${ }^{95}$

\section{Distribution of Ownership Interests}

Since the need for intervention under section 8(a)(2) lessens as the interests of management and labor converge, courts and the NLRB should consider the extent to which employee-ownership holdings create an area of shared labor-management interests beyond that commonly found in traditionally owned firms. When employee ownership interests are substantial and widespread, and the area of shared labor-management interests is correspondingly great, there is little reason for judicial or administrative intervention. If ownership interests are relatively evenly divided among employees, any self-interested reluctance on the part of employee bargaining representatives to press demands harmful to a company's financial position generally will reflect the self-interest of other employees.

In many worker-owned firms, however, a large majority of employees may be nonshareholders ${ }^{96}$ or may have only insignificant ownership interests. ${ }^{97}$ In such cases, the convergence of labor-management interests associated with employee ownership may not occur. Under these circumstances, courts should be willing to hold a worker-owned firm subject to section 8(a)(2), especially if a large percentage of employee representatives own disproportionately large interests in the company relative to the ownership interests of employees as a whole. ${ }^{98}$

the NLRA, and could be added to the current statute as a proviso following section $8(a)(2)$.

94. By exempting from section $8(a)(2)$ only those firms in which assisted labor organizations represent the interests of employee-owners as effectively as could fully independent labor organizations, the amendment would promote beneficial labor-management cooperation without sacrificing $\mathrm{em}$ ployee-owners' legal protection against detrimental support.

95. Cf. Gurdon, supra note 2, at 305 (if no meaningful influence fows from ownership, many employees treat ownership interests as simple financial investments).

96. The Chicago and Northwestern Transportation Company furnishes one example. Less than one-fourth of the firm's 15,000 employees owned company stock as of 1976 . Union leaders, who are among those with substantial investments in the company, claim stock ownership has not affected their willingness to strike. In line with company hopes, however, union-management relations have been unusually smooth. See Thomson, supra note 1 , at 7 .

97. See Long, supra note 6, at 758 .

98. Substantial ownership interests may co-opt employee bargaining representatives. The potential conflict of interest presented by such a situation might also merit judicial scrutiny under the duty 


\section{Employee Participation in Management Decisionmaking}

Courts and the NLRB also should consider the extent of employee participation in management decisionmaking. If all employees have an opportunity for significant participation in setting company policy on subjects ordinarily within the scope of collective bargaining, ${ }^{99}$ employees may further their own interests directly without the constraints of an adversarial negotiating process. In such cases, employee-owners can influence management decisionmaking through a combination of methods: electing managers, placing representatives on the board of directors, or serving on various in-plant labor-management committees. ${ }^{100}$

Within any worker-owned firm, however, the significance of employee participation depends upon the degree of control employees exercise over particular decisions, the issues subject to employee influence, and the level at which that influence is exercised. ${ }^{101}$ Determining whether employee participation in a particular firm is sufficient to support judicial and administrative nonintervention may often involve a complex inquiry by the trier of the fact. ${ }^{102}$ In making that determination, certain factors merit close attention. Workers are most likely to acquire influence in decisionmaking through parity ${ }^{103}$ or majority representation on the board of directors and other management bodies. Elaborate organizational structures apparently designed to provide for an employee voice in management decisions should not, however, furnish support for judicial nonintervention if in reality workers' representatives are relegated to a minority voice in

of fair representation, see supra note 59 , or under more general doctrines of fiduciary responsibility.

99. See supra note 69 (describing subjects coming within statutory duty to bargain).

100. Workers in cooperatives generally have access to all of these avenues of influence: important financial and policy decisions require shareholder ratification; lesser management decisions are overseen by worker-elected directors; and various special problems fall within the province of stockholder committees. See K. BERMAN, supra note 6 , at 8 . Similar avenues of participation exist to varying degrees in other worker-owned firms, with mixed results. See D. ZWERDLING, supra note 6, at 5-6.

101. The possible range and significance of each of these factors are considered in detail in $P$. BERNSTEIN, supra note 22 , at $47-61$.

102. The history of the American Cast Iron Pipe Company, a South Bend, Indiana, machine tool manufacturer, demonstrates the potential danger of confusing the opportunity for democratic management with its implementation. The company was turned over to workers by its founder, who hoped to institute a participatory system of worker self-governance that would operate to the benefit of labor and the public. Formally, employees were given considerable voice in the firm's management: worker representatives participated in the selection of directors, received access to company records, and shared in the operation of the company's disciplinary council. In practice, however, management representatives on the board of directors outvoted workers' representatives on most policy decisions. One commentator described American Cast Iron Pipe's participatory structure as a "mask" for one of the city's "last great nonunion bastions of corporate paternalism." See Zwerdling, Looking for Workers' Control, in 2 WORKING PAPERS FOR A NEW SOCIETY 1, 13-14 (1974).

103. Parity representation alone is no guarantee of employee influence in setting company policy. In the Vermont Asbestos Group, production workers and management officials initially were represented equally on the company's board of directors. Nonetheless, important decisions were still made by the executive board that ran the firm before its conversion to employec ownership. See supra note 29. 
most policy decisions. ${ }^{104}$ Courts and the NLRB should also consider the extent of employee access to management-level information concerning the company's operations, financial status, and future prospects. ${ }^{105}$ Such access is necessary if employees are effectively to take advantage of opportunities to participate in setting policy. ${ }^{106}$ Finally, courts and the NLRB should determine the extent to which procedural guarantees protect the rights of individual employees. Employees should be assured, for example, that criticism of majority-supported managerial policies or procedures will not provoke reprisals from management or from fellow workers. ${ }^{107}$

\section{Conclusion}

The conventional approach to section $8(\mathrm{a})(2)$, based on judicial and administrative experience with the adversarial interaction of labor and management, has only a limited value when applied to worker-owned firms. Conventional section $8(a)(2)$ remedies are necessary to protect the bargaining process only in those worker-owned firms with a narrow distribution of ownership interests and with little worker participation in management. In many other worker-owned firms, the underlying goals of the NLRA are best served by permitting imaginative and flexible labor-management interaction unconstrained by conventional section $8(a)(2)$ doctrine.

104. As in the American Cast Iron Pipe Company, see supra note 102, the influence of employees' representatives may be neutralized by rules allowing management to choose a majority of the members serving on labor-management committees. Such a relegation of worker representatives to a minority voice is common in worker-owned firms in which managers hold controlling blocks of shares. See D. ZWERDLING, supra note 6, at 5-6. Similar problems arise when employee ownership is effected through an ESOP trust, with management-appointed trustees exercising voting control over trust stock. Id. at 67.

105. At the Vermont Asbestos Group, for example, management refused to provide financial and managerial information desired by the employee-owners. See D. ZWERDLING, supra note 6, at 59.

106. See P. BERNSTEIN, supra note 22 , at $69-74$; W. Whyte, supra note 6 , at 14 . Bernstein suggests that in addition to displacing workers from their position as co-managers, the withholding of information may generate mistrust between labor and management that reduces economic efficiency and leaves a company in a worse position than before worker participation was first attempted.

Management may withhold information from workers out of habit or a desire to maintain industrial secrecy. P. BERNSTEIN, supra note 22, at 70. Managers at the Vermont Asbestos Group, for example, blamed production workers for leaking confidential information to the public. $D$. ZWERDLING, supra note 6, at 59. In addition, management may feel that workers lack the ability to use such information. P. BERNSTEIN, supra note 22 , at 71 . The experience of the plywood cooperatives, however, demonstrates that, given an opportunity, workers can educate themselves sufficiently to participate productively in business decisions. See D. ZWERDLING, supra note 6, at 99.

107. See P. BERNSTEIN, supra note 22 , at 75 ; P. Pitegoff, supra note 53 , at 4 . The possibility that a majority coalition of employees might act in ways detrimental to the interests of a minority is lessened by the duty of fair representation, which requires the bargaining representative to represent fairly all employees in a bargaining unit. See supra note 59. 
